\title{
ON CYNICISM: Activist and Artistic Responses to Corruption in Ghana
}

\author{
GIRISH DASWANI \\ University of Toronto \\ (D) https: / / orcid.org/0000-0002-1685-5957
}

On July 1, 2014, Ghana's Republic Day, a group of educated and middle-class Ghanaians calling themselves Concerned Ghanaians for Responsible Governance protested the government's bad track record on corruption. What started off as the hashtag \#OccupyFlagStaffHouse on Twitter feeds quickly circulated on social networking sites and turned into a protest that took Ghana by storm, surprising even its organizers. Hundreds walked through the rain toward Flagstaff House, the seat of government, and presented a petition to representatives of President John Mahama, the leader of Ghana's then ruling National Democratic Congress (NDC). The OccupyFlagstaffHouse organizers comprised mainly young Ghanaian professionals who used social media to galvanize a following of people from different parts of the political spectrum. Live coverage of the event drew public attention to the political corruption of the country's elected leaders. A few weeks later, as a result of the demonstration's success, members of Ghana's educated elite, with help from a younger generation of activists, formed OccupyGhana. On July 11, 2014, they launched a campaign called "Red Friday." To indicate their solidarity, Ghanaians were encouraged to wear locally made clothing and to post photos and videos of themselves wearing red (a color usually worn at a funeral) on various social media sites with the hashtags \#RedFriday or \#OccupyGhana. 


\section{\#RedFriday}

BECAUSE WE LOVE OUR COUNTRY.

TheBlacklarrator

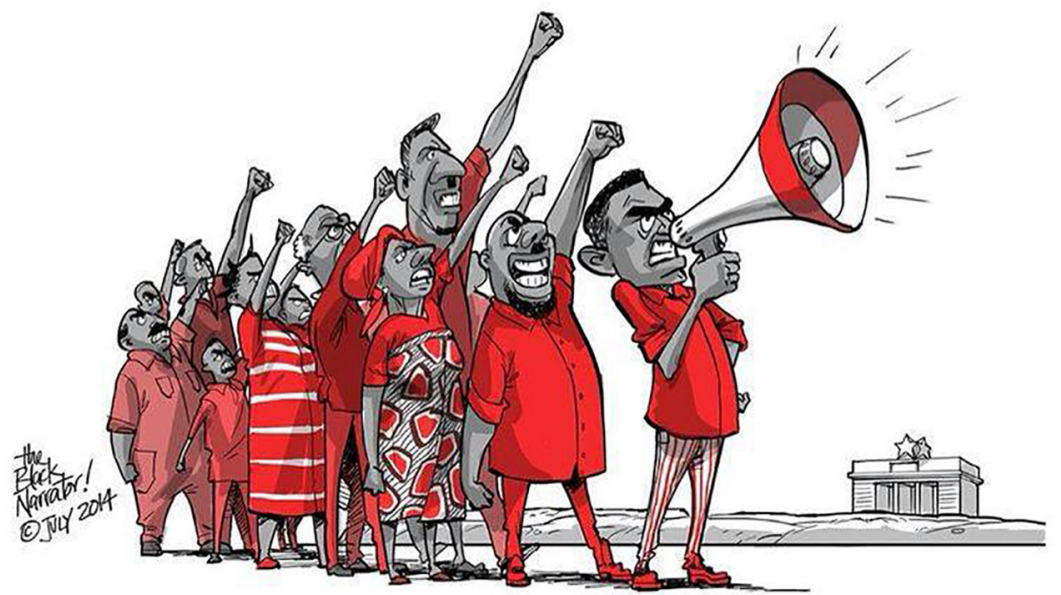

ff The Black Narrator

Figure 1. “\#RedFriday. Because We Love Our Country”' Image by The Black Narrator.

Almost a year after the OccupyFlagstaffHouse demonstration, I met up with two of the younger leaders of OccupyGhana at a café on Accra's Oxford Street. Nana Akwasi, a lawyer in his thirties and one of the organizers of the demonstration, had just been selected for a Mandela Washington Fellowship, a flagship program created by Barack Obama's Young African Leader's Initiative. Golda, who had worked for various NGOs in Ghana, had played a central role in igniting the spark that led to the 2014 protest. During the demonstration she hung a placard around her neck that read, "The king is naked!" and told the media that "the king thinks that he is in fancy clothes, but the king is naked. Nobody is telling him the truth." Both Nana Akwasi and Golda expressed satisfaction at having sent a message to the president and seemed excited at the prospect of effecting further change. Nana Akwasi added that he and others were motivated by "a desire to do good," for they were "demanding accountability," "fighting for social justice," and "fighting corruption," he said.

In May 2015, Nana Akwasi and other activists helped the Ghanaian actress Yvonne Nelson organize the street protest and night vigil titled "Dumsor Must 
Stop.” Dumsor, which translates from Twi into "off-on" (dum-sor), served as a metaphor for Ghana's energy crisis and the more recent cases of corruption associated with Mahama's government. An electricity load-shedding regime of twelve hours on and twenty-four hours off was affecting domestic and non-domestic consumers of power, and critics squarely placed the blame for this erratic power supply on the hands of the government and the corruption of the political elite. The hashtag \#dumsormuststop attracted more than a thousand people, who cut across different segments of Ghana's population. The rapper and singer Wanlov the Kubolor was among the artists who participated. He had just released a song critical of Ghana's corrupt politicians. His cynical attitude toward politicians in Ghana served as the inspiration for many of Wanlov's songs. According to the singer, the political elite had no reason to change. Wanlov, like other members of Ghana's artistic scene, such as the satirical cartoonist Bright Ackwerh, reveal how entertainment and popular culture serve as important outlets for political critique by the country's less privileged.

An undeniable global aspect adheres to these recent examples of Ghanaian activism. Since 2011, protest movements such as the Arab Spring, the May 15 Movement in Spain, and the \#Occupy Movement have helped shape our shared political and social landscapes (Juris and Razsa 2012; Graeber 2013). As elsewhere, neoliberal state forms, global financial crises, and the corruption of an entrenched political elite informed the activism in Ghana. These protest movements have demonstrated a trend of nontraditional elites rising to visibility through networked counterpublics (S. Jackson and Welles 2015) and have highlighted how new forms of political agency are tied closely to urban relations (Jiménez and Estalella 2013) and overlapping similarities observed between political movements across geographical locations (Obadare and Willems 2014; Werbner, Webb, and Spellman-Poots 2014; Lazar 2015). Yet the Ghanaian activist response to corruption and dumsor also showed significant differences from these global movements, and their resistance likewise formed part of the everyday practices of grassroots civic mobilization particular to Ghana (Oduro-Frimpong 2018). In the United States, for example, satirical activism, which began in the 1980s and gained momentum in the 2000s, worked alongside the \#Occupy protests (Haugerud 2013). In Ghana, satirical artists and OccupyGhana activists held different ideas about political action and its outcomes and were embedded in distinct sets of social relations.

In this article I argue that while both activists and artists were responding to the cynicism of other middle-class Ghanaians, those who seemed indifferent to the corruption of Ghana's political elite, they differed in their class orientations, 
in their motivations for and expectations of future change, and in their organizational forms of sociality. If cynicism around corruption and political change motivated activism in Ghana, OccupyGhana activists and popular artists demonstrated different kinds of activist subjectivities that demand further analytical attention. In what follows, I ask how activist and artistic responses to cynicism provided space for variation and difference and how Ghanaian activists' imagining of political action drew on different sources for inspiration. I reveal that if the members of OccupyGhana emulated a middle-class liberal democratic narrative of overcoming that stemmed from a utopian horizon, Ghanaian artists embraced skepticism toward the future, which allowed them to keep one eye firmly on the haunting presence of colonialism and neoliberal capitalism.

My analysis of the period just before and after the December 2016 national elections provides a vantage point from which to reflect on Ghanaian activism as a space where cynicism thrives in multiple ways. When writing about cynicism, anthropologists commonly refer to Peter Sloterdijk's (1995) Critique of Cynical Reason. ${ }^{1}$ Working some forty years after the Second World War, Sloterdijk was responding to a specific historical moment in West German politics, one characterized by general disillusionment and an insidious form of violence he called "cynicism" (Shea 2010, 146). He described cynicism as an "enlightened false consciousness" that allowed Western society to matter-of-factly declare that this is how "things really are" without doing anything about it (Sloterdijk 1995, 193). Acknowledging that not everyone is cynical in the same way, anthropologists have found the concept of cynicism useful for understanding how citizens in various times and places critically respond to political indifference and to a perceived moral crisis (Steinmüller 2014, 2016). While some anthropologists have used the concept to analyze authoritarian states and the subtle or comparatively docile forms of resistance afforded their citizens (Yurchak 1997, 2006; Navaro-Yashin 2002), others working in countries with multiparty systems (e.g., Lebanon) have described how cynicism can coexist alongside political mobilization and hope (Hermez 2015, 507-8) or how (in the context of an occupied Palestine) it can "be a form of awareness and a motor for action" (Allen 2013, 16). Building on this work, the present article calls for a more expansive ethnographic engagement with how the politically engaged respond to cynicism and what their approach tells us about politics as understood through the relationship between indifference (born from cynicism) and critiques involving action.

Drawing on fieldwork that took place in Accra, Ghana, between 2015 and 2017, I reflect on cynicism through two kinds of activist orientations: one located 
in a middle-class, future-oriented project of political change, and another representing the views of the lower classes and embodied in popular performance styles that embraced contradiction by poking fun at the duplicity of politics. In the first part of my essay, I focus on the activists from OccupyGhana, middle-class Ghanaians motivated by a desire to do good. ${ }^{2}$ Since the restoration of multiparty politics in Ghana in 1992, terms such as good governance have ironically crept into the language of activism (Ferguson 2010) and become synonymous with opposition to corruption (Muir and Gupta 2018, S6). While this activism of the supposed good partakes in a global neoliberal agenda that identifies citizen engagement and participation as important for promoting democracy (Hammett 2018, 71) and anti-corruption discourses (Hasty 2005), it remains an elite project embodied by neoliberal ideas about the future. The activists from OccupyGhana were members of Ghana's new middle class who had access to university education and resources, drew on advanced communication skills, and embodied an activist subjectivity "interlaced with a 'postcolonial condition' that speaks in the language of rights, recognitions, and choices" (Stoler 2016, 33).

In the essay's second section, I discuss the work of Ghanaian artists hailing from the emergent urban intermediate class, people less concerned with expected political change than with making fun of the present through satire and humor (Boyer 2013; Haugerud 2013; Molé 2013; Dağtas 2016; Shipley 2017). Rather than engaging with "good governance" and "anticorruption" discourses, Ghanaian artists used popular culture to critique elite forms of knowledge by evoking "the presence of 'us, the poor' in contrast to 'them, the rich and powerful'" (Barber 2018, 7-12). Rather than expecting things to change for the "good," these artists used popular culture as a form of "critical aesthetics" (Chari 2017a, 167) to raise awareness about the contradictions of politics through artistic parody prone to transgressive humor. I compare them to Ananse, the human-spider trickster figure of Ghanaian folklore (Shipley 2015; Donkor 2016) and to Sloterdijk's (1995) kynicism, a reference to acts that are deemed cheeky, vulgar, or provocative and therefore reside in the realm of satire. An Ananse-style kynicism resembles the satirical acts of poking fun at authority that artists in Ghana and elsewhere in Africa are involved in when challenging the excesses of power of the continent's postcolonial leaders (Weiss 2004; Obadare 2009; Hammett 2010; J. Jackson 2013; Shipley 2013; Oduro-Frimpong 2014, 2018; Barber 2018; Limb and Olaniyan 2018).

By attending to the social actions and experiences that characterize these two groups, I ask what it means to take cynicism, and activism against and despite cynicism, as one's ethnographic object. In exploring how individuals relate to cyni- 
cism differently, I pay attention to the creative potential of political protest, as well as to its limits and interruptions (Chari 2017b; Li 2019). Sloterdijk wrote about cynicism in the wake of a conservative turn in German politics after the uprisings of 1968 (Shea 2010, 146). As his philosophical meditation on cynicism continues to inform the various registers of political indifference experienced by citizens in contemporary nation-states, we need to address its adequacy for ethnographic description (Steinmüller 2011, 33). I argue that looking at people's responses to cynicism from the comparative perspective of activists and artists in Ghana constitutes a fruitful endeavor, because each group participated in politics and speculated about their nation's future in distinct ways. In the following section, I reveal how a local critique of cynicism stems from a specific vantage point and particular genealogy - a nation-state in the global South to which "good governance" has been preached for decades and where dumsor and corruption have recently become the target of grassroots mobilization.

\section{DUMSOR AND CORRUPTION}

The 2014 OccupyFlagstaffHouse demonstration gathered momentum as a social and electronic movement among citizens frustrated with the political and economic situation in Ghana: dumsor and increasing cases of corruption within governmental agencies were some of the main triggers of activism. While power outages (commonly known as "light off") and corruption are not uncommon in Ghana's recent history, dumsor entered the popular vocabulary in 2012, crystalizing as a symbol of resistance and social commentary on corruption. As this "infrastructure disruption" (Silver 2015) intensified, with rolling blackouts continuing for days at a stretch, businesses struggled to keep up with the ever-rising cost of the fuel needed to power generators, as well as the costs of servicing those machines. The activists I spoke to shared the impression that dumsor had raised its ugly head at a time when corruption had penetrated government structures at the highest levels.

Golda told me that she had always known that there was "corruption" in Ghana, but not how "openly . . . they [the politicians] made it about themselves." The NDC government had barely been in power for a hundred days when Golda described things as having shifted from "bad" to "horrid," tweeting to her friends, "I'm so fed up that I'm going to sit in front of Flagstaff House and not move." She received many responses and ultimately met with the people who helped initiate the first protest, which took place in April 2013. Called “One Simple Step," it had, to Golda's disappointment, a poor turnout of only ten people. Nana Akwasi 
told me that he was thinking about "the tro tro driver, the taxi driver," a profession affected by fuel shortages when he went online to organize the OccupyFlagstaffHouse demonstration a year later. Indeed, the country's corruption discourses form rhetorical components of political life through which people publicly talk about their disappointment with the nation-state and its political elite (Gupta 1995; Smith 2007; Pierce 2016; Sanchez 2016; Muir and Gupta 2018). While corruption is not a phenomenon limited to Ghana or the global South, but also involves multinational institutions and the unequal structures of the global economic system, corruption discourses have become a legitimate way for Ghanaian citizens to engage with politics, evaluate state practices, and voice a political critique of the postcolonial state (Hasty 2005).

The accusation of corruption for political leaders goes back to Ghana's first post-independence leader Kwame Nkrumah (1957-1966), whose political opponents accused him of this crime and who was replaced by Dr. Kofi Busia after a military coup. Busia (1969-1972), later overthrown by Colonel Ignatius Acheampong (1972-1978), also faced charges of corruption. Student protests and middle-class outrage against corruption played a crucial role in the rise and fall of later regimes: they were present in the fight against Acheampong and also first to support Jerry Rawlings in 1979 and the early 1980s and then to criticize his regime later in the $1980 \mathrm{~s}$. While the structural adjustment programs of the $1980 \mathrm{~s}$ and the shift to a multiparty democracy and to neoliberal policies in the $1990 \mathrm{~s}$ have contributed to the increase of utility prices and the lack of infrastructural development, Ghanaians continue to blame "corruption" for the social and economic ills of the country.

If the first thirty years of postcolonial independence favored single-party regimes in Africa, the pendulum later "swung back again as significant sections of society weighed into politics with a gusto which had not been witnessed since the heyday of nationalism" (Nugent 2012, 376; see also Mueller 2018, 43). Africa's "second wave" of protests, which began in the 1990s after the breakup of the Soviet Union, was followed by a post-2011 "third wave" (Mueller 2018) that saw communication technology become central to activism in Ghana and Africa more widely (Nyabola 2018; Dwyer and Molony 2019). Some of the cases of corruption dominating the Ghanaian news channels and online media sites since 2012 involve government agency contracts given to private companies for work not done, whereby large sums of money were either never fully accounted for or never seen again. Rather than constituting isolated acts of bribery involving bureaucrats, these cases circulated through social media to indicate how a systematic form of 
corruption, which took the shape of outright theft by political leaders and their cronies, had become the norm. In 2013, a Ghanaian high court judge described these illegal activities as "create, loot, and share" (GhanaWeb 2013). ${ }^{3}$ This (real and perceived) increase in corruption, or at least the blatant way in which it was being done, produced a popular anxiety about what the state is, where it is located, and what it means to be a citizen who cares, and who cares to respond (Parry 2000).

While changes to the constitution allowed for democratic elections and the legal right to demonstrate freely, political choice in Ghana has remained constrained between two major parties since the early 2000s - the NDC, which is the democratically elected, political offshoot of Rawling's PNDC, and the National Patriotic Party (NPP), a pro-business and center-right party — both of which have faced accusations of corruption. For some, the 2014-2015 wave of anticorruption activism was reminiscent of the 1995 Kum-me-preku ("Kill me once and for all”) demonstration, which constituted a direct response to the 17.5 percent value-added tax that the NDC government, then led by Rawlings, had placed on goods and services. Organized by a group of political opposition leaders, including the NPP's current flagbearer Nana Akufo-Addo, calling themselves Alliance for Change, this protest faced violence by armed government supporters, leading to the death of four people. The OccupyFlagstaffHouse demonstration was a litmus test on Ghana's democracy and the ability of its citizens to protest government corruption. It had a demonstrable effect in helping the NPP win the 2016 national elections. Yet OccupyGhana was caught between two activist agendas: a critique of the state, which for some comes with a class-based agenda focusing on the fate of the working classes, and the creation of a space in which the neoconservative, market-oriented NPP can operate against the ruling NDC.

\section{OCCUPYGHANA: AN ACTIVISM OF THE “GOOD” AND CYNICISM}

When I first met Nana Akwasi, he told me that his work with OccupyGhana concerned a "struggle for good governance," and that the fight against corruption was inextricably linked to "happiness." His activism echoed an Aristotlean virtue ethics that lends importance to the cultivation of acts deemed good and through which ethical practice is often viewed as a form of "human flourishing" (Laidlaw 2014) or as a way to lead "a life worth living" (Mattingly 2014). What some members of OccupyGhana considered "good" (good governance, good citizenship) is closely intertwined with a neoliberal development model advocated by international agencies such as the International Monetary Fund (IMF) and the World 
Bank (Hammett 2018). In the 1980s, structural adjustment policies saw deep cuts in social spending and, while a precarious macroeconomic equilibrium was temporarily restored, these policies introduced new ways of imagining democratic politics. In the 1990s these Western international agencies shifted their priorities from structural adjustment to a new emphasis on democratic participation associated with multiparty politics, democratic elections, and an active civil society. Recent protest leaders in Ghana are usually members of the new middle class who emerged from the economic liberalization policies of the late twentieth century, especially after the 2000 election victory of the NPP under John Kufuor and his government's free-market governance policies.

Cynicism was a word used by Yofi Grant, one of the leaders of OccupyGhana, to describe the political indifference of other middle-class Ghanaians to ongoing government corruption. "People are tired," he despaired. "There is so much to complain about that you scream yourself hoarse and the government does not seem to do enough about anything." He continued: "Corruption is not new. But when it gets to a point when it starts becoming institutionalized, you get a sense that the government is not doing enough, for they are engaged with corruption.” Yofi was an investment banker in Ghana. Like other Ghanaians, he was tired of watching politicians cheat, steal, and lie, but also tired of the general cynicism that characterized the response to corruption. Most votes were "bought," he told me, and bound by the codes of collective identity that descended into what he called "tribalism." In addition, many people did not think that voting for either of the main political parties mattered. But Yofi was of the opinion that people should "know better," that better arguments or reasonable opinions ought to be adopted in place of weaker ones, and changes voluntarily accepted for the good of all. Activism was his response to the cynical reasoning he found in other middle-class Ghanaians: an indifference to what was happening around them and the notion that things will never really change. He was especially tired of those Ghanaians he called "neo-neutrals": those not doing anything or not responding to the corruption happening in front of them. Take his Facebook post from June 2016:

Scandal after scandal, story after story, compendium of faux pas. . . . and yet folks, especially all those mugwumps, the neo-neutrals, who think it's not theirs to comment and condemn, sacrifice their conscience and intellect, and those who are unflinching in hailing with reckless abandon ... shamelessly defending the indefensible ... think that things should remain, because ... ? One can list too many issues, a whole lot of "challenges," embarrassing viola- 
tions of governance, eldritch misgivings, which should raise the eyebrows of the hardest ossified cynic. It's not about bipartisanship, it's about what is right and what is wrong.

The people Yofi refers to as the hardened "cynics" or the "neo-neutrals" in his Facebook post resemble the modern cynics described by Sloterdijk (1995). At this level, cynicism helps reproduce the fantasy of the state (Navaro-Yashin 2002) that allows Ghanaian citizens to accommodate pre-established relations (e.g., corruption) and to go on with their lives (as is). This approach assumes that people are conscious of their reality but act as if they are not. In other words, cynicism instils the kind of indifference and complacency that provides people with moral opinions about what really "is," as well as the opportunity to fade into anonymity even as they are dragged down by these inadequacies. It was the cynicism exhibited by many Ghanaians that both motivated Yofi and other activists to respond to corruption.

In an interview aired on the Ghanaian television program State of the Nation, another leader of OccupyGhana, a lawyer named Ace Ankomah, said, in response to a tweet from a viewer telling Ace that he should not bother with his activism but instead take these issues to court: "Look at this person, comfortably sitting in his home watching TV . . this kind of person constitutes part of the problem that we have . . . they don't care." If the "they" are the cynics, the activist becomes the person who cares to respond to such cynicism with what is "right" and who holds others accountable for their wrongs to reveal the greater truth. Ace distanced himself from what the interviewer described as "the middle class." He explained that the "so-called" middle class was around but "had checked out of Ghana." By this he meant that the majority of middle-class citizens were largely disconnected from the issues faced by ordinary Ghanaians because they had "resolved all their problems. . . . If their roads are bad, they drive four-wheel drives. If there is no water, they have boreholes. . . . If there is no electricity, they have gen[erator] sets." Ace and others like him saw themselves as working for the good and on behalf of those too cynical or afraid to take any action. Some of the Ghanaian activists I spoke to noted the "assumed cynicism" (Hermez 2015, 508) of others and their ability to shield themselves from life's contradictions as underlying motivations for their own response of not exhibiting cynicism about future political change and instead doing one's "duty."

For Golda, another activist from OccupyGhana, activism became "infused with cynicism" (Hermez 2015, 509). Golda is an environmental and women's 
rights activist. She represents a different generation of activist from the senior leaders of OccupyGhana. In her mid-thirties, born and raised in Accra, and a graduate from the University of Ghana, Golda took a couple of years off after completing university to travel to different countries in Africa, as well as to the UK and the United States, before returning to Ghana in 2008. In 2009 she registered her own NGO and started working on environmental issues. Golda, who initiated the first attempt to organize a protest against corruption, was actively involved on social media sites, notably Facebook and Twitter, and asked her online community to intervene: "Why is it that we're so intelligent on social media but every time I said, 'let's do something,' nobody wanted to step forward? It was all about being online, and hiding behind [the internet]," she said to me. While Twitter, Facebook, and WhatsApp have helped protest leaders coordinate events and connect across vast distances, they also threatened to replace face-to-face interactions and give the illusion of a movement against corruption on the ground.

Golda became an active participant in OccupyGhana, the group formed after the second Twitter-fueled protest. But by 2016 she had left the movement. When I asked her why, she replied, "I was skeptical about most of the leading members and what their genuine intentions for the proletariat could be." Like some other younger leaders of OccupyGhana, she felt that the movement was becoming more hierarchical and partisan (favoring the main opposition NPP). Golda felt disappointed with the internal politics of activism, especially since she felt her organization represented the same (patriarchal) elite interests of the existing political parties. The older generation of activist leaders had taken over the reins from the younger members and had drawn a line between acceptable and unacceptable forms of critique and methods of protest. When a founding member of OccupyGhana joined the NPP in the run-up to the December 2016 elections but did not leave the movement, the group split. Together with some other former members of OccupyGhana, Golda helped create the Citizen Ghana Movement. Citizen Ghana initiated the process to legalize the Freedom of Information Act, which allowed citizens to request information about the financing of public projects. Again, however, she did not stay long: "I joined Citizen Ghana with high hopes, then lost the enthusiasm. . . . I left when some of the members of OccupyGhana that I suspected of having dark intentions decided to infiltrate that group too."

In 2016 Golda explained to me that she had become disappointed with activism and how her health and marriage had suffered from her involvement. Naisargi N. Dave's work $(2016,2017)$ on animal activists in India has had an important influence on my analysis with regard to how cynicism, as located in the incon- 
sistencies that arise from the irresolvable contradictions activists face, can lead to "exhaustion." It has helped me understand that Golda's experience may not differ too much from that of other activists whose ethical dilemmas have direct effects on their body, including on its capacity to be affected (Dave 2016, 2017). The activist fight — and the contradictions it posed — had taken a lot out of Golda. When reflecting back, she said to me:

I'm not sure if I can express everything, because it is so much, and most of it eludes vocabulary. But what I can say in addition is that the situation in Ghana, politically, has become one of being stuck between the sea and a hard place. No choice is good enough to rescue Ghana and the future generations, and at the time, the feeling of deep disappointment in the available options was very, very fresh and very, very heavy on the soul. They promised better governance [and] then shafted us without lubrication. Then handed us over to all their cronies to shaft. And they looked us in the face while they did it. The heartbreak was real, and everywhere we looked, there was no one better to rescue us. Activism therefore began to feel like stage drama. You're passionate about it, but you know at the end of the day, it's not real. This makes you tired.

Golda's disappointment was tied to a "deep cynicism about the possibility of social and political change" (Greenberg 2014, 7). In her work on Serbian student activists, Jessica Greenberg $(2014,8)$ argues that such a "politics of disappointment" is inherent to the contradictions of lived democratic practice, where political life is dominated by certain why questions, such as "Why are activists acting like self-interested politicians?" and "Why are my actions only benefiting a few?" Golda's stepping away from activism and her critique of OccupyGhana constituted less a retreat from politics than the experience of a transition linked to an intimate act of making sense of things. It was a "refusal" to comply with a certain kind of activist politics (Simpson 2014, 2016; McGranahan 2016, 320), the acceptance of a limit reached due to one's refusal to be an activist within certain preconditions and criteria set by others. Rather than a definitive judgment on what needed to happen next, exhaustion and disappointment provided Golda with an alternative experience of being an activist.

In the following section I focus on the work of activist-artists, who, in a way reminiscent of Mikhail M. Bakhtin's (1984) ideas of the grotesque and the obscene, use satire and parody as a form of response and refusal. These carnivalesque performances serve as "acts of familiarization" in which "hierarchical exclusions 
can be subverted . . . through actions that not only flout but also exaggerate the conventions of a ruling elite" (Weiss 2009, 26). However, instead of "the low" turning the tables on "the high," these artists created a "potent symbolic space" for connecting social classes and ethnic groups to poke fun at Ghanaian politics (Weiss 2009, 29). Able to communicate their work and to speak to the masses through digital media, these artists shape moral and social dialogue through their ability to move between and blend multiple registers and by addressing problems of social inequality and poverty that affect an increasing number of Ghanaians (Shipley 2013). I consider them closer to Ananse-style kynics than to modern cynics who recognize the limits of long-term futurity as an effective horizon of sociopolitical change (Weiss 2009; Scott 2014). While a logic of demanding accountability was encoded in the future-oriented practices of members of OccupyGhana, the Ghanaian artists I spoke to participated in an ethic of social leveling through a creative performance more focused on responding (to the) now through humor and satire.

\section{ANANSE-STYLE KYNICISM AND HUMOR}

While contradictions form part of the cynic's life, the kynics do not simply complain. Instead, they use their personally experienced contradictions as a combative force for humor and satire. This outlook overlaps nicely with the model of Ananse the human-spider trickster figure of Ghanaian folklore. Ananse is often described as an immoral character who possesses a worldly wisdom that carries him through life. He reminds us that life is not simply about established meanings but also about contradictions, which are intrinsic to life (Donkor 2016, 17). In the telling of Ananse stories, the aim is to question dominant ideologies and create an interaction between the storytellers and their audience that allows both sides to explore the limits of the social order and consider the possibility of alternative outlooks (Shipley 2015; Donkor 2016). Writing about the African postcolony, Achille Mbembe (2001, 128-29) has referred to an "intimacy of tyranny" whereby ordinary people unable to directly confront the excesses of the elite use humor as a way to "guide, deceive and toy with power." While humor and "mimicry" (Bhabha 1994) provide for the temporary disruption of state authority or serve as a form of endurance for the powerless and can simultaneously be appropriated by the powerful, Ebenezer Obadare (2009) and others (Hammett 2010; Oduro-Frimpong 2014, 2018) have argued that humor in postcolonial Africa has not been taken seriously as an active form of resistance. This derives, in part, from the literature's existing preoccupation with the African state (see Bayart 1993) and the democratizing effects of civil society, which places organizations at the center of analysis. 
More recent literature from Africanist scholars suggests a change to a greater focus on artistic protests as forms of resistance (Barber 2018; Limb and Olaniyan 2018). The Ghanaian artists I know did not always describe themselves as activists, nor did they expect their art to create real change in politics. Instead, they saw their work as a necessary response to corruption, one that challenged the ruling elite and provided inspiration for other forms of activism. Having gained social notoriety and value in contemporary Ghana through the circulation of images, texts, and music, as well as through the concomitant production of moral commentaries (Shipley 2017), they are thus comparable to the trickster Ananse. Their approach is reminiscent of the Ghanaian concert-party theater performances of the twentieth century, which formed part of a wider history of transatlantic performances aimed at dramatizing the frustrations of the underprivileged classes while providing a unique perspective on colonialism and nationalist identity (Cole 2001; Shipley 2004).

A currently celebrated artist in Ghana whose activism and satirical cartoons started during the dumsor crisis is Bright Ackwerh. Bright was a university student doing a master's degree in fine arts at the Kwame Nkrumah University of Science and Technology when dumsor disrupted his ability to work from home. He described to me how, between the time he had applied to do a postgraduate degree and the moment he gained admission, his tuition fees had increased by almost 800 percent. The withdrawal of government subsidies for his postgraduate studies, the songs that emerged from Ghana's energy crisis, as well as his own experience with dumsor sparked his political sensibilities. Bright also draws inspiration from other artists and popular musicians, including the Ghanaian hip-hop duo the FOKN Bois and the Nigerian activist-musician Fela Kuti. He is especially drawn to their unapologetic manner of relaying messages and believes that artists who are "politically conscious have the power to upset the system." In reference to Fela Kuti's 1978 musical performance in Accra (especially his song "Zombie”), Bright stated that it was music that "inspired the audience to hit the street and riot against what was then very corrupt practices in Ghana government."

Bright's first satirical piece dates from 2015 and is called "Ode to FOKN Bois." It depicts the FOKN Bois duo molesting a map of Ghana while famous spectators from popular culture and politics, including Kwame Nkrumah, look on with glee. Bright was forced to work on this piece at internet cafés as these places had the generators he needed during the height of the dumsor crisis. Bright said that the controversial rap duo enjoyed "fucking" with Ghana and revealing many of the social injustices faced by ordinary Ghanaians. He was not sure how his piece would 
be received, but it marked the start of his friendship and future collaborations with Wanlov the Kubolor, whom I will discuss in greater detail below. In 2016, Bright created the cover art for The Corruption-Dumsor Mixtape curated by Wanlov, which featured a number of songs by Ghanaian artists criticizing corruption and dumsor and won Bright the Kuenyehia Prize for Contemporary Ghanaian Art.

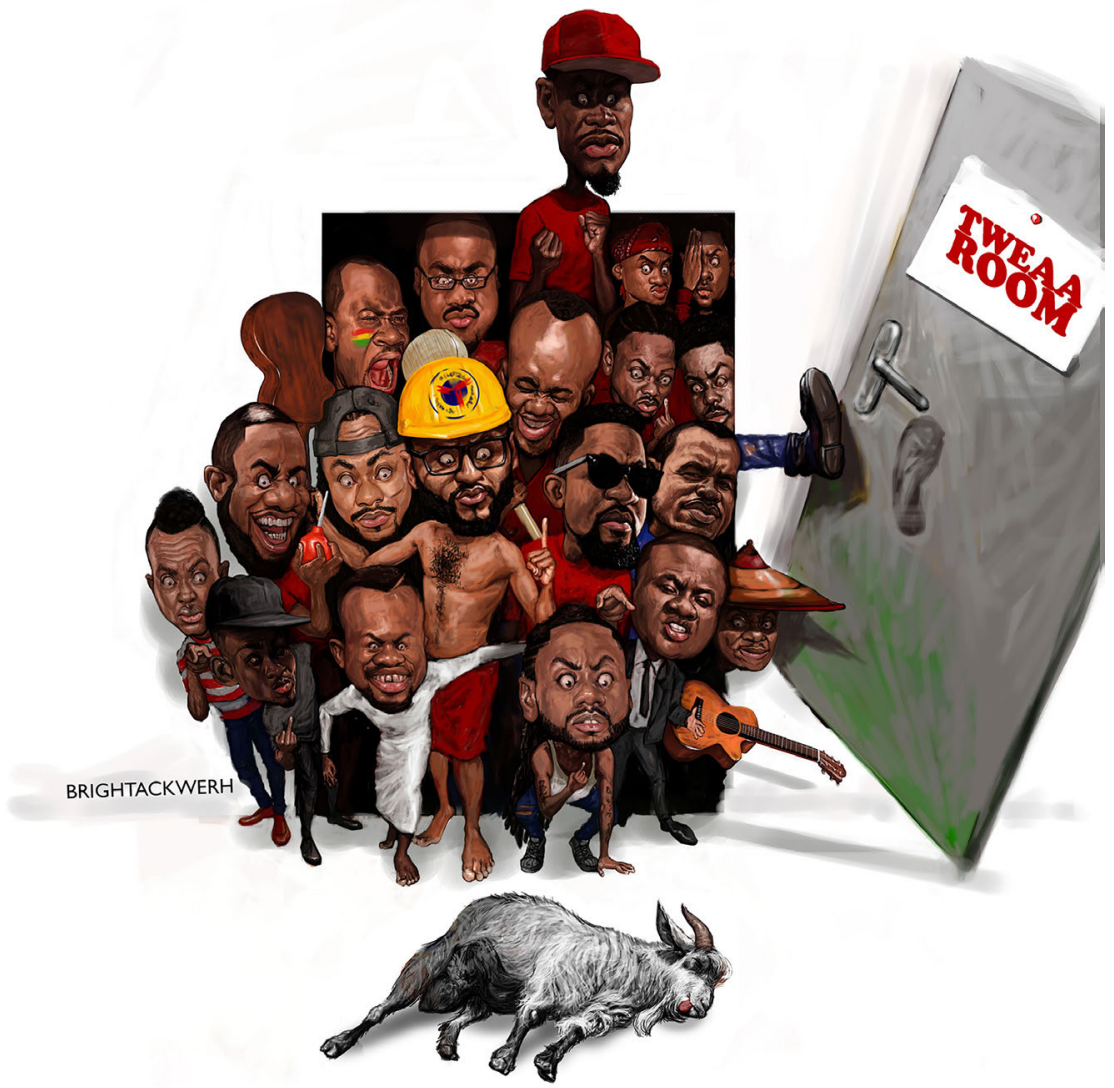

Figure 2. “Tweaa Room.” Image by Bright Ackwerh.

Bright's subsequent humorous drawings, poking fun at popular, religious, and political figures, include a depiction of Ghana's then president John Mahama wearing a motorcycle helmet and driving a 2012 Ford Expedition with a goat (also wearing a helmet) in the front seat. "Expedition" was a comical response to the news that, as vice-president, Mahama had accepted an SUV as a gift from a Burkinabe construction company that had been given several large government contracts by the Ghanaian president. 


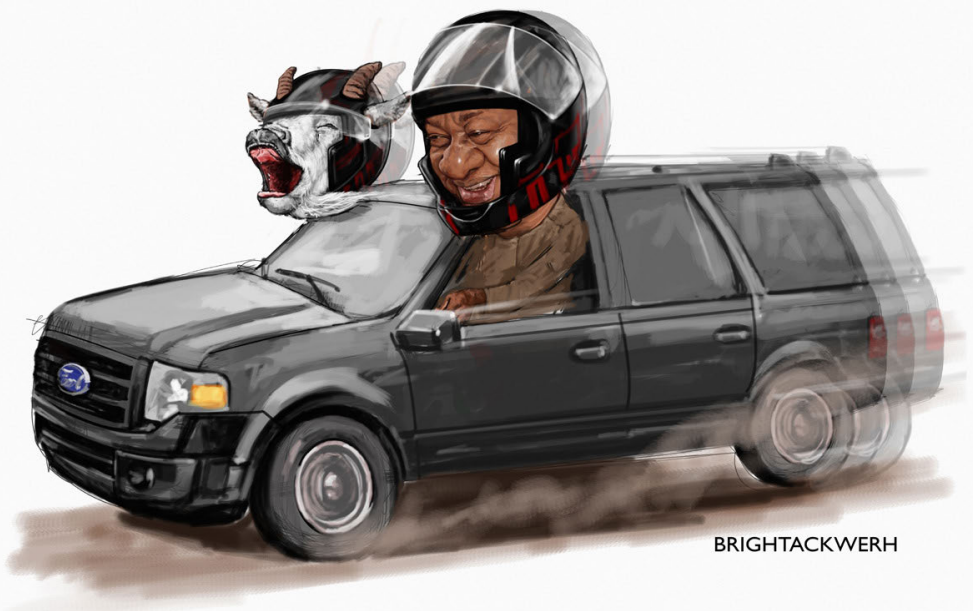

Figure 3. "Expedition.” Image by Bright Ackwerh.

Bright explained to me the launch of investigations for that case. Mahama's guilt would justify efforts to impeach him, Bright said. Yet he also knew that this was never going to happen. Illustrations such as Bright's point to the disillusionment Ghanaians feel with the sincerity of politicians and processes of accountability.

The case was open and shut when they claimed the car was no bribe and had been added to the national pool. I wanted to capture that "getting away with it" happy feeling on his face.

The helmet referred to a video and pictures of the president speeding out of his residence on a powerful motorcycle to supposedly inspect floods in Accra, images that had gone viral. The goat, which has become a feature of Bright's artwork, originated with something the president had said in Botswana in 2015. Responding to a question about the OccupyGhana demonstrations, President Mahama claimed he had "dead goat syndrome":

I have seen more demonstrations and strikes in my first two years. I don't think it can get worse. It is said that when you kill a goat and you frighten it with a knife, it doesn't fear the knife because it is dead already. 
Since then, these infamous words have been reinterpreted in several other cartoons and have become the butt of many jokes. By using framing devices such as parody and the analogical appositions of parallel social contexts otherwise temporally disparate, Bright exposes the contradictions of Mahama's position on corruption. Such satirical caricatures reinvest public statements and images with new value and allow for further debate around corruption by critiquing the actions of the cartoon's subject (President Mahama) and undermining the legitimacy with which political leaders act and speak (Jackson 2013). Bright and others in Ghana's artistic scene used direct and shocking expressions of humor to highlight the absurdity of politics. Bright described his work as one piece in a larger jigsaw puzzle and cited Wanlov's music as an important element helping him establish his own style of satirical art.

Wanlov the Kubolor (Emmanuel Owusu Bonsu), a rapper and musical artist of Ghanaian and Romanian descent, serves as an iconic reference point and inspiration for many artists and spoken word performers engaged in challenging political corruption in Ghana. Wanlov grew up in Accra and attended Asisadel College, an Anglican Boys School in Cape Coast, where he started rapping and became involved in the local circuit of Cape Coast and Takoradi. In 2000 he traveled to the United States to pursue his university degree in computer science, but he dropped out after two years to dedicate himself to his musical career. After facing arrest for a high-speed motorcycle chase with the police in the United States, he spent a short time incarcerated before returning to Ghana in 2007. Wanlov later teamed up with his childhood friend and Ghanaian rapper M3NSA to form the group FOKN Bois. The duo, known for their satirical lyrics and their comical and witty demeanor, have referred to their songs as "therapy," since they are able to say things that Ghanaians are thinking about but afraid to say themselves.

I first met Wanlov in April 2016 in Accra. I texted to tell him I was in Ghana and wanted to meet to speak about his recent interventions on corruption (which included songs, interviews, and collaborations with other artists). He replied within minutes and invited me to join him in his one-bedroom apartment, which also serves as his recording studio. Sporting long dreadlocks, a trimmed beard, and a violet-colored wrap around his waist (teasingly called a skirt by some), Wanlov picked me up from the main road and walked me to his home. Wanlov had a personal recording studio in his bedroom, which also served as his living, dining, and guest room. There was a huge Samsung TV screen linked up to a computer and other recording devices, including speakers and a microphone. When I asked Wanlov about his latest song on corrupt politicians titled "Never Go Change," he 
replied that it was not his first song on corruption. He wanted to set the record straight - he "wasn't an opportunist." "People kept asking me why I had changed my style [from rap], why I was singing about corruption and politics," he said; "but they don't remember that one of my songs in my first album from 2007 was about this [corruption]."

He then played me the song "50th Dependence" from his album Green Card. In it he was rapping in pidgin about the same problems - light off, greedy politicians, and police extortion. The song's conception coincided with Ghana's celebrations for fifty years of independence. At the time, Wanlov was living in the United States and learned that Ghana had borrowed large sums of money, used to buy expensive cars for politicians. It was not until the most recent couple of years that Wanlov had started conceptualizing a new album titled Red Card: The Minstrel Cycle. The title refers to the showing of a red card to Ghana's corrupt politicians, as in a soccer match, as well as to the rapper's role as a joker or minstrel who uses humor to tell the uncomfortable truth to people in power.

Humor is an important part of Wanlov's personal philosophy and approach to music as "soft resistance." As he said to me: "I'm not into these complaining songs without cheek." He described his songs as a "response to discomfort," and humor as an important part of his "self-therapy": "I am reacting to my environment in a way that excites me and allows me to laugh at them [leaders, politicians] when they get upset."

The underlying inspiration for many of Wanlov's songs was the artist's cynicism regarding politics and politicians in Ghana, which, according to him, had no reason to change. Wanlov cared deeply about the pollution caused by plastics on Ghana's beaches and the government's lack of care for basic sanitation, which caused many to defecate by the sea in black plastic bags. In the video for a song he made in collaboration with the Ghanaian artist ELi, titled "Gold Coast," Wanlov raps naked, squatting in a large drain next to the beach, with a picture of then President Mahama's face covering his genitals. Part of his rap goes:

Swimming with my people, surrounded by our torpedoes, floaters sinkers suspenders, this practice for be suspended. Until further notice, store your golden plastic bags, the black ones, and drop them for Flagstaff [the seat of government]. [He then makes a farting sound as he walks away]. ${ }^{4}$

Another of Wanlov's songs, "Never Go Change," is more serious and critical of corrupt politicians who seem not to care about the plight of ordinary Ghana- 
ians. It is played to rhythmic guitar strumming, sung in pidgin and with a melodic voice (unlike his usual rapping style). Wanlov explained that he was inspired to write this song during dumsor and while learning to play a highlife guitar tune at his friend's (the Ghanaian musician Kyekyeku) house in East Labadi, a residential neighborhood in Accra. Unlike most other homes in the capital, Kyekyeku's house had power. Since it was on the same grid as the one that supplied electricity to the Castle, the president's official residence, his home never suffered power cuts. Here are some of the lines from the song:

Dey no dey care about light off, dey get dema generators

Dey no dey care if the road roff, dey get dema land cruisers

Dey no dey care about traffic, dey get dema police escorts

Dey no dey care about justice, dey get dema police and courts

So why dey go change oh, dey never go change

Dey never go change oh, dey never go change

Dey never go change oh, dey never go change

Dey never go change oh, why dey for change?

The song focuses on why Ghana's elite need not change nor concern themselves with the suffering of ordinary Ghanaians. It denounces injustice, whereby the few in Ghana who had electricity powered by generators were the same who could afford Land Cruisers and therefore not as susceptible to the accidents and deaths that frequently occurred on badly maintained roads. They were further the ones who could bribe the police and judges to avoid getting punished for their crimes. The song's lyrics progressively get darker: "So we for kill them all chale, we for kill them all. Cut off dem heads and spill dem blood on the walls." Wanlov calls into question the distinction between the elite and the powerless and ends his song with a question to all Ghanaians: "Like you, you go change?" Wanlov did not believe that things would truly change without some kind of destruction and rebirth, maintaining that Ghana's colonialist power regime would continue to only benefit the rich and powerful, without offering an avenue of escape for the poor. In his description of the YouTube video for "Never Go Change," Wanlov writes, "if the video makes no sense to you it is because dumsor, pollution, poverty \& corruption in [G]hana make no sense to me." ${ }^{5}$ On the cover of Wanlov's recently released album Red Card (illustrated by Bright), Flagstaff House is on fire, and lying on the ground next to it, in a pool of blood, are the decapitated heads of several state figures (from left to right: Mahama, Akufo-Addo, Rawlings, Tiwaa Addo-Danquah, 
Kufuor), as well as the symbols of Ghana's two main political parties (an elephant for the NPP and an umbrella for the NDC) (see figure 4). ${ }^{6}$

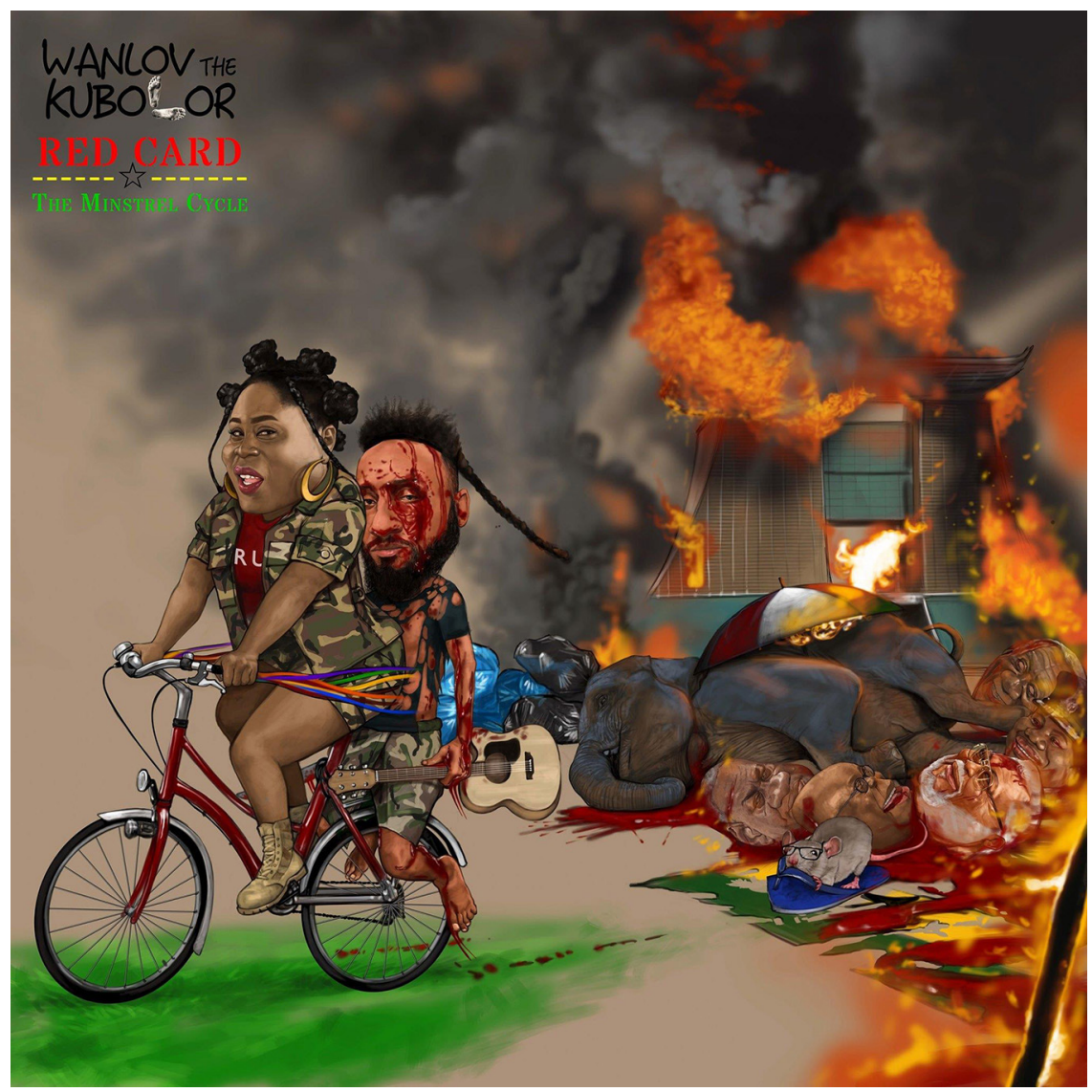

Figure 4. Album cover of “Red Card:The Minstrel Cycle.” Image by Bright Ackwerh.

Wanlov's and Bright's feelings about Ghana were filled with the contradictions attached to the persistence of corruption, regardless of which government held power. While sitting on the floor of Wanlov's apartment one evening in 2017, I listened to him telling me how the country's problems with corruption went back to British colonial times in Ghana. How could things change when colonial countries continued to interfere in African economies and influence present-day African politics? For Wanlov, postcolonial Ghana reincarnated colonial evils that had never been fully expelled. This echoed Mbembe's (2001, 14-16) point about the distinctiveness of the postcolony as the "time of entanglement" that "encloses multiple durées . . . an interlocking of presents, pasts, and futures.” It also speaks 
to Ann Laura Stoler's (2016, 33) description of colonial presence as "a past that is imagined to be over but persists, reactivates, and recurs in transfigured forms." The claims of democratic citizenship and the presence of neocolonialism presented a contradiction impossible to resolve. Bright himself admitted that wanting to change the world and acknowledging that you cannot was a contradiction he held while creating his art pieces. "There is a saying, 'Some people own the world. We just live in it," he told me. "There is already an agreed system of doing things that is different from what we are presented with. Some of these structures have already been set, and, even when there is a change of power, [things] cannot be changed that easily." Corruption persisted because Ghanaian politicians have "obligations that they have to fulfil. . . . to the people who fund them, not to the people who have elected them," he said.

Even after Akufo-Addo and the NPP defeated the Mahama government in the 2016 elections, Bright's work continued to highlight the imbalance of power and the neocolonial nature of the relationships between Ghana and its international financiers, including China, the United States, and Britain. In a cartoon he created in 2017, Ghana's sitting president, Akufo-Addo, is pictured protecting his food - a local dish called banku - from intrusive British dignitaries who want to eat it. They include Princess Anne, Tony Blair, and then foreign secretary Boris Johnson.

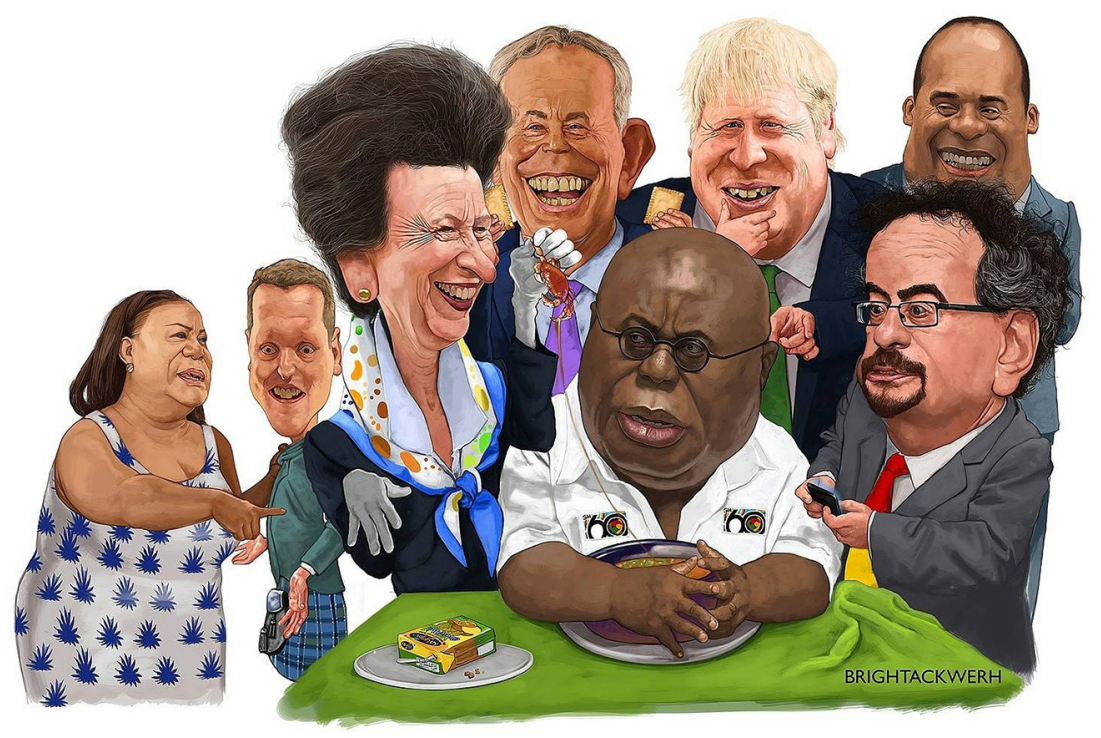

Figure 5. “ky3 mu p3.” Image by Bright Ackwerh. 
Entitled "ky3 mu p3" (Twi for "share it equally") it is named after a Ghanaian game in which the person about to eat has to announce "No ky3 mu p3" or risk dividing their food equally with anyone who passes by. Bright conceived of this cartoon during Ghana's sixtieth anniversary of independence, which took place just after Ghana had changed governments. In the image, the president is wearing his official anniversary attire and protecting his favorite local food. Just as Ghana has become a profitable site of future-oriented speculation, Bright wanted to "speculate" on the nature of economic agreements and trade contracts made behind closed doors and, thus, potentially exploitative of Ghana's economy and natural resources. He said to me:

During that period, we had received a lot of visits from foreign presidents, prime ministers. . . I I asked, "What is it about this government that suddenly everybody wants to come down here and negotiate some private, behindclosed-doors meeting? History has taught us that these things don't just happen.... And usually when they say, “closed doors," they don't want us to know. So I made a painting which featured some of the prominent British dignitaries that we received because of the history Ghana has with Britain. I referenced that game because I felt like they were trying to take something. I don't know what it was. And I'm not going to know.... So let me speculate and I'll speculate as wildly as I can.

Deploying satire and parody to bring supposed corruption into view, artists such as Wanlov and Bright use contradictions to stretch binaries and think beyond normative models of resistance. Uploading and circulating their work on social media, they provide a greater number of Ghanaians access to political critique. Their work serves to entertain and surprise even as it makes some people feel uncomfortable. These artists are not modern cynics (Sloterdijk 1995) who do nothing about the present political situation. Neither are they kynics in the Greek style or direct examples of Michel Foucault's (2012) “truth-telling” (see also Englund 2018). Instead, through their Ananse-style kynicism and their ability to transform aesthetic output into political critique, artists like Bright and Wanlov do not hold onto the expectation that things will change for the better. Rather, they describe their work as a "response" to the discomfort they experience, and as a way to make fun of the political situation. Though they work toward developing critical awareness about the political present, they recognize their creations' limitations. As Wanlov said to me: "Someone once asked me if I wanted to make music that 
was timeless, like Fela Kuti, Bob Marley. But I do not believe in that. Something that is time-restricted cannot be time-less." Rather, he and Bright mock social conventions and polite and normative forms of communication, sharing their artistic material for public consumption so as to excite, upset, and provoke conversation. They share what Bakhtin (1984, 107-8, italics in the original) has described as a "carnival sense of the world," an artistic genre that possesses a "life-creating and transforming power" through a shared focus on the "living present," a reliance on "experience ... and on free invention," and a rejection of a single narrative in favor of a "multi-toned narration, the mixing of high and low, serious and comic."

\section{CONCLUSION}

The concept of cynicism has provided me with a productive way to reflect on different activist orientations toward corruption in Ghana just before and after the country's 2016 elections. The assumption that people are conscious of state corruption but choose to ignore this knowledge in their daily life can be compared to a modern form of "cynicism" (Sloterdijk 1995) associated with the "fantasy" of keeping the state intact (Navaro-Yashin 2002). I have described how, apart from corruption and dumsor, the cynicism of other middle-class Ghanaians played a role in motivating the actions of activists from OccupyGhana as well as those of Ghanaian artists. Cynicism emerged as an accusation (Steinmüller 2016) to create an ethical distance from those not willing to respond to corruption. Sloterdijk's use of the term, however, gives the impression of an oppositional politics: either one's indifference leads one to do nothing or one acts bravely, performing social critique (Steinmüller 2011). Yet in responding to corruption and to the cynicism of others, Ghanaian activists and artists held different positionalities and followed separate paths to commentary, ones that demonstrate different kinds of activist sociality and subjectivities.

Through a close study of two groups of activists in Ghana-members of OccupyGhana and popular artists - this article has described how activist communities differ from each other and the distinct ways in which they imagine the future. While activists from OccupyGhana did not question the path toward market liberalization built on a message of speculative hope, Ghanaian artists asked whether this was a future worth buying into. I have argued that the subjective orientations of OccupyGhana activists and artists differentiated themselves through class orientations and their particular kind of embeddedness in Ghanaian politics. I have suggested that the OccupyGhana critique of cynical reason was situated within a different genealogy of politics, one in which discursively transportable idioms such 
as "good governance" and "good citizenship" have proven important to activist accounts of fighting corruption.

Most activists from OccupyGhana came from Ghana's new middle class, well-educated members of a privileged group whose activism drew motivation from a combination of social justice and anti-corruption discourses that I have called an "activism of the good." As activists, members of OccupyGhana separated themselves from the rest of the middle class who did not respond to corruption and whom they described as cynical about political change. If activism provided them with the opportunity to speak for a common good, it also created different outcomes for its participants. After the NPP won the December 2016 elections, Yofi Grant resigned as an executive member of OccupyGhana to become the chief executive officer of the Ghana Investment Promotion Centre, working to build Ghana's transnational ties to overseas investors. He had supported the NPP all along and had helped campaign for them during the run-up to the elections. He did not see his work of building Ghana's trade alliances as separate from his earlier role as an activist. Instead, activism and politics went hand in hand with building the necessary conditions for a neoliberal future. Golda, however, revealed how the teleological narrative of activism can get disrupted and lead to the undoing of everyday life. She came to eventually question the "good" of activism and turned cynical about its outcomes even as she held onto the hope that things will change for the better. Their different activist positionalities and divergent political sensibilities complicate a simple reading of an activism of the good, in fact infusing it with irony.

I have also examined an Ananse-style kynicism from the perspective of Ghanaian artists who poke fun at the duplicity of politics. Ghanaian artist responses to corruption provided a different aesthetics of critique, where performances and the perspectives of the lower classes mattered more, and where skepticism about real political change proved inherent to the activist response. Their artistic performances allowed Ghanaians of different social backgrounds to participate in social critique through a generative recontextualization of a song or a cartoon to express their sense of exclusion, displacement, and frustration (Weiss 2009; Barber 2018). Through my discussion of Ghanaian artists such as Bright and Wanlov, I have demonstrated that an Ananse-style kynicism is a critical impulse associated with popular culture that decenters power from the postcolonial state. By embracing contradictions, artists like Wanlov and Bright embraced a living dialogue between apparent opposites and provoked Ghanaians to view politics in a new way (Bakhtin 1984). Drawing attention to the spectral promises and the failures of 
postcolonial politics and neoliberalism, they kept one eye on hope without holding onto the idea that things will necessarily improve. Wanlov, for example, did not expect his music to change things for the better, due to the continued presence of colonialism in Ghana's political and economic system. He said to me: "If I am hoping human beings to change, to hear my music and change, I will forever walk crooked." For Wanlov and Bright, an Ananse-style kynicism was more important as a creative source of critique that allowed ordinary Ghanaians to express their frustrations and to imagine a different future from the one presented by their nation's leaders. Perhaps it is not the contradictions inherent in a democratic politics that disappoint and exhaust, but, rather, the challenges of seeing and embracing these contradictions in the first place.

\section{ABSTRACT}

By considering how Ghanaian activists and artists engage with different forms of cynicism in their attempts to fight corruption, this article reflects on two kinds of activist orientations: one located in future-oriented projects of political change, and another embracing contradiction by poking fun at the duplicity of politics. I argue that while the cynicism of other middle-class Ghanaians served as an important catalyst for activist action, it is important to look at cynicism and its politics from the perspective of Ghanaians who become disappointed and skeptical about change and artists who are concerned with embracing contradictions and making fun of the present through satire. By attending to the social actions and experiences that characterize these two groups, I ask what it means to take cynicism, and activism against and despite cynicism, as one's ethnographic object. [cynicism; Ghana; corruption; activism; humor]

\section{ABSTRACT}

Dis paper na about de two different way aluta and jolly-jolly people for Ghana dey show say dem "disappoint and lose hope" when dem dey fight magomago: one way na to struggle and believe say tomorrow go betta, and de oder way na to join yabis, abuse and comedy to fight wayo politics. My own argument here be say, even when $e$ be true say many ordinary people for Ghana join aluta because dem don disappoint and lose hope for how magomago don spoil tings, e make big sense also to put eye for how aluta people for Ghana wey disappoint for sake of magomago come lose hope so tey dem no believe tings fit change for betta again and dose jolly-jolly people wey join yabis togeda with abuse now to fight magomago. When I put eye for dis two different way people dey behave when dem dey fight magomago, my plan na to show wetin dey happen when person wey don lose hope and disappoint come join aluta struggle with am to show how people dey behave. [somebody wey no born yestee; Ghana; magomago; aluta; fool pass] 


\section{NOTES}

Acknowledgments This essay has benefited from conversations with respected colleagues in several institutions at which I presented earlier versions. They include Osaka University, the National University of Singapore, the University of Toronto, and the London School of Economics and Political Science. I am grateful to the thoughtful suggestions made by the anonymous reviewers for Cultural Anthropology, to the editorial work of Jessica Lockrem and Petra Dreiser, and to the insightful feedback of Katherine Blouin, Amit Desai, Andrea Muehlebach, Alejandro Paz, and Brad Weiss. The research for this article was made possible by the support of family and friends in Ghana and funded by SSHRC Institutional Grants from the University of Toronto Scarborough. Abstract translated into Nigerian Pidgin English by Rotimi Fasan. Thanks to Joseph Oduro-Frimpong for making this happen.

1. I thank my colleague Naisargi Dave for pointing me to Sloterdijk's (1995) work on cynicism. Dave's $(2016,2017)$ work on animal activists in India, and her engagement of cynicism as located in contradictory thinking, proved instrumental in helping me think about the inconsistencies that arise from a liberal politics and how it can lead to an activist exhaustion.

2. The ethical project of trying to foster an idea of the "good," the desire to do good in one's political environment and to strive to live in light of such an ideal, seem to fit well with the aims of many activists from OccupyGhana (Robbins 2013; Mattingly 2014). However, we also need to recognize how the "good" might become an elite or middle-class project that can be rendered technical (Li 2007) — as an affective sentiment in support of development and state-building projects (Chalfin 2010) or as an already integral part of the structure of feeling and action located in a neoliberal moral economy (Muehlebach 2012).

3. "The "create, loot and share" comment was made by Supreme Court Justice Jones Dotse during the hearing of the $€ 40$ million judgment debt paid to Waterville Holdings Ltd. and the GHc51.2 million paid to Ghanaian businessman, Alfred Agbesi Woyome (see GhanaWeb 2013).

4. ELi, "Gold Coast, ft Wanlov," music video, YouTube, September 12, 2016, https://www. youtube.com/watch? $\mathrm{v}=$ BUbYYIfUtSM.

5. Wanlov the Kubolor, "Never Go Change," music video, YouTube, May 19, 2015, https:// www.youtube.com/watch?v=yaT4o8-eOgU.

6. Wanlov the Kubolor, "Red Card: The Minstrel Cycle," music album, October 1, 2019, https://song.link/album/i/1481869711.

\section{REFERENCES}

Allen, Lori

2013 The Rise and Fall of Human Rights: Cynicism and Politics in Occupied Palestine. Stanford, Calif.: Stanford University Press.

Bakhtin, Mikhail M.

1984 Problems of Dostoevksy's Poetics. Edited and translated by Caryl Emerson. Minneapolis: University of Minnesota Press.

Barber, Karin

2018 A History of African Popular Culture. Cambridge, UK: Cambridge University Press.

Bayart, Jean-François

1993 The State in Africa: The Politics of the Belly. London: Longman.

Bhabha, Homi K.

1994 The Location of Culture. London: Routledge.

Boyer, Dominic

2013 "Simply the Best: Parody and Political Sincerity in Iceland." American Ethnologist 40, no. 2: 276-87. https://doi.org/10.1111/amet.12020. 
Chalfin, Brenda

2010 Neoliberal Frontiers: An Ethnography of Sovereignty in West Africa. Chicago: University

Chari, Sharad of Chicago Press.

2017a "The Blues and the Damned: (Black) Life-that-Survives Capital and Biopolitics." Critical African Studies 9, no. 2: 152-73. https://doi.org/10.1080/21681392.2017.1 331457.

2017b “Detritus.” Somatosphere, October 30. http://somatosphere.net/2017/10/detritus. html.

Cole, Catherine M.

2001 Ghana's Concert Party Theatre. Indianapolis: Indiana University Press.

Dağtaş, Mahiye Seçil

2016 "'Down with some things!': The Politics of Humour and Humour as Politics in Turkey's Gezi Protest." Etnofoor 28, no. 1: 11-34. https://www.jstor.org/ stable/43823940.

Dave, Naisargi N.

2016 "On Contradiction: Humans, Animals, and 'The Way Things Are." Paper presented at Princeton University, March 3.

2017 "Something, Everything, Nothing; or Cows, Dogs, and Maggots." Social Text 35, no. 1 (130): 37-57. https://doi.org/10.1215/01642472-3727984.

Donkor, David Afriyie

2016 Spiders of the Market: Ghanaian Trickster Performance in a Web of Neoliberalism. Bloomington: Indiana University Press.

Dwyer, Maggie, and Thomas Molony, eds.

2019 Social Media and Politics in Africa: Democracy, Censorship and Security. London: Zed Books.

Englund, Harri

2018 "The Front Line of Free Speech: Beyond Parrhêsia in Finland's Migrant Debate." American Ethnologist 45, no. 1: 100-111. https://doi.org/10.1111/amet.12602.

Ferguson, James

2010 “The Uses of Neoliberalism.” Antipode 41, supp. 1: 166-84. https://doi.

Foucault, Michel org/10.1111/j.1467-8330.2009.00721.x.

2012 The Courage of Truth: The Government of Self and Others II; Lectures at the Collège de France, 1983-1984. Edited by Frédéric Gros. Translated by Graham Burchell. New York: Picador.

GhanaWeb

2013 "Judges Blast NDC Looting Brigade." GhanaWeb, June 21. https://www. ghanaweb.com/GhanaHomePage/NewsArchive/Judges-blast-NDC-looting-

Graeber, David brigade- 277555 .

2013 The Democracy Project: A History, a Crisis, a Movement. London: Penguin Books. Greenberg, Jessica

2014 After the Revolution: Youth, Democracy, and the Politics of Disappointment in Serbia.

Gupta, Akhil Stanford, Calif.: Stanford University Press.

1995 "Blurred Boundaries: The Discourse of Corruption, the Culture of Politics, and the Imagined State." American Ethnologist 22, no. 2: 375-402. https://doi.

Hammett, Daniel org/10.1525/ae.1995.22.2.02a00090.

2010 "Political Cartoons, Post-Colonialism and Critical African Studies." Critical African Studies 2, no 4: 1-26. https://doi.org/10.1080/20407211.2010.10530755.

2018 "Engaging Citizens, Depoliticizing Society? Training Citizens as Agents for Food Governance." Geografiska Analer: Series B, Human Geography 100, no. 2: 64-80. https://doi.org/10.1080/04353684.2018.1433961. 
Hasty, Jennifer

2005 "The Pleasures of Corruption: Desire and Discipline in Ghanaian Popular Culture." Cultural Anthropology 20, no. 2: 271-301. https://doi.org/10.1525/ can.2005.20.2.271.

Haugerud, Angelique

2013 No Billionaire Left Behind: Satirical Activism in America. Stanford, Calif.: Stanford University Press.

Hermez, Sami

2015 "When the State is (N)ever Present: On Cynicism and Political Mobilization in Lebanon." Journal of the Royal Anthropological Institute 21, no. 3: 507-23. https://

Jackson, Jennifer doi.org/10.1111/1467-9655.12249.

2013 Political Oratory and Cartooning: An Ethnography of Democratic Process in Madagascar. Malden, Mass.: Wiley-Blackwell.

Jackson, Sarah J., and Brooke Foucault Welles

2015 "Hijacking \#myNYPD: Social Media Dissent and Networked Counterpublics." Journal of Communication 65, no. 6: 932-52. https://doi.org/10.1111/jcom.12185.

Jiménez, Alberto Corsín, and Adolfo Estalella

2013 “The Atmospheric Person: Value, Experiment, and 'Making Neighbors' in Madrid's Popular Assemblies." HAU 3, no. 2: 119-39. https://doi.org/10.14318/hau3.2.008.

Juris, Jeffrey, and Maple Razsa

2012 "Occupy, Anthropology, and the 2011 Global Uprisings." Hot Spots, Fieldsights, July 27. https://culanth.org/fieldsights/series/occupy-anthropology-and-the2011-global-uprisings.

Laidlaw, James

2014 The Subject of Virtue: An Anthropology of Ethics and Freedom. Cambridge: Cambridge University Press.

Lazar, Sian

2015 “'This is not a parade, it's a protest march': Intertextuality, Citation, and Political Action on the Streets of Bolivia and Argentina." American Anthropologist 117, no. 2: 242-56. https://doi.org/10.1111/aman.12227.

Li, Tania Murray

2007 The Will to Improve: Governmentality, Development, and the Practice of Politics. Durham, N.C.: Duke University Press.

2019 "Politics, Interrupted." Anthropological Theory 19, no. 1: 29-53. https://doi. org/10.1177\%2F1463499618785330.

Limb, Peter, and Tejumola Olaniyan, eds.

2018 Taking African Cartoons Seriously: Politics, Satire and Culture. East Lansing: Michigan University Press.

Mattingly, Cheryl

2014 Moral Laboratories: Family Peril and the Struggle for a Good Life. Berkeley: University of California Press.

Mbembe, Achille

2001 On the Postcolony. Berkeley: University of California Press.

McGranahan, Carole

2016 “Theorizing Refusal: An Introduction." Cultural Anthropology 31, no. 3: 319-325.

Molé, Noelle J. https://doi.org/10.14506/ca31.3.01.

2013 "Trusted Puppets, Tarnished Politicians: Humor and Cynicism in Berlusconi's Italy." American Ethnologist 40, no. 2: 288-99. https://doi.org/10.1111/amet.12021.

Muehlebach, Andrea

2012 The Moral Neoliberal: Welfare and Citizenship in Italy. Chicago: University of Chicago Press. 
Mueller, Lisa

2018 Political Protest in Contemporary Africa. Cambridge, UK: Cambridge University Press.

Muir, Sarah, and Akhil Gupta

2018 "Rethinking the Anthropology of Corruption: An Introduction to Supplement 18.” Current Anthropology 59, supp. 18: S4-S15. http://doi.org/10.1086/696161.

Navaro-Yashin, Yael

2002 Faces of the State: Secularism and Public Life in Turkey. Princeton, N.J.: Princeton University Press.

Nugent, Paul

2012 Africa since Independence. 2nd ed. New York: Palgrave Macmillan.

Nyabola, Nanjala

2018 Digital Democracy, Analogue Politics: How the Internet Era Is Transforming Politics in Kenya. London: Zed.

Obadare, Ebenezer

2009 "The Uses of Ridicule: Humour, 'Infrapolitics' and Civil Society in Nigeria." African Affairs 108, no. 431: 241-61. https://doi.org/10.1093/afraf/adn086.

Obadare, Ebenezer, and Wendy Willems

2014 "Introduction: African Resistance in an Age of Fractured Sovereignty." In Civic Agency in Africa: Arts of Resistance in the 21st Century, edited by Ebenezer Obadare and Wendy Williams, 1-24. Woodbridge, Suffolk: James Currey.

Oduro-Frimpong, Joseph

2014 “'Better Ghana [Agenda]'? Akosua's Political Cartoons and Critical Public Debates in Contemporary Ghana.” In Popular Culture in Africa: The Episteme of the Everyday, edited by Stephanie Newell and Onookome Okome, 131-54. New York: Routledge.

2018 "This Cartoon Is a Satire: Cartoons as Critical Entertainment and Resistance in Ghana's Fourth Republic.” In Taking African Cartoons Seriously: Politics, Satire, and Culture, edited by Peter Limb and Tejumola Olaniyan, 133-58. East Lansing: University of Michigan Press.

Parry, Jonathan

2000 “The 'Crisis of Corruption' and the 'Idea of India': A Worm's Eye View.” In Morals of Legitimacy: Between Agency and System, edited by Italo Pardo, 27-56. Oxford: Bergahn Books.

Pierce, Steven

2016 Moral Economies of Corruption: State Formation and Political Culture in Nigeria. Durham, N.C.: Duke University Press.

Robbins, Joel

2013 "Beyond the Suffering Subject: Toward an Anthropology of the Good." Journal of the Royal Anthropological Institute 19, no. 3: 447-62. https://doi.org/10.1111/14679655.12044.

Sanchez, Andrew

2016 Criminal Capital: Violence, Corruption and Class in Industrial India. Delhi: Routledge India.

Scott, David

2014 “The Tragic Vision of Postcolonial Time.” PMLA 129, no. 4: 799-808. https://doi. org/10.1632/pmla.2014.129.4.799.

Shea, Louisa

2010 The Cynic Enlightenment: Diogenes in the Salon. Baltimore: Johns Hopkins University Press.

Shipley, Jesse Weaver

2004 “The best tradition goes on': Audience Consumption and the Transformation of Popular Theatre in Neoliberal Ghana." In Producing African Futures: Ritual and Reproduction in a Neoliberal Age, edited by Brad Weiss, 106-140. Leiden: Brill. 
2013 Living the Hiplife: Celebrity and Entrepreneurship in Ghanaian Popular Music. Durham, N.C.: Duke University Press.

2015 Trickster Theatre: The Poetics of Freedom in Urban Africa. Bloomington: Indiana University Press.

2017 "Parody after Identity: Digital Music and the Politics of Uncertainty in West Africa." American Ethnologist 55, no. 2: 249-62. https://doi.org/10.1111/ amet.12476.

Silver, Jonathan

2015 "Disrupted Infrastructures: An Urban Political Ecology of Interrupted Electricity in Accra." International Journal of Urban and Regional Research 39, no. 5: 984-1003.

Simpson, Audra https://doi.org/10.1111/1468-2427.12317.

2014 Mohawk Interruptus: Political Lives across the Borders of Settler States. Durham, N.C.: Duke University Press.

2016 “Consent's Revenge." Cultural Anthropology 31, no. 3: 326-33. https://doi. org/10.14506/ca31.3.02.

Sloterdijk, Peter

1995 Critique of Cynical Reason. Translated by Michael Eldred. Minneapolis: University of Minnesota Press. Originally published in 1983.

Smith, Daniel Jordan

2007 A Culture of Corruption: Everyday Deception and Popular Discontent in Nigeria. Princeton, N.J.: Princeton University Press.

Steinmüller, Hans

2011 “The State of Irony in China." Critique of Anthropology 31, no. 1: 21-42. https://doi. org/10.1177\%2F0308275X10393434.

2014 "A Minimal Definition of Cynicism: Everyday Social Criticism and Some Meanings of 'Life' in Contemporary China." Anthropology of This Century 11. http://aotcpress. com/articles/minimal-definition-cynicism-everyday-social-criticism-meaningslife/.

2016 "Introduction." In Irony, Cynicism and The Chinese State, edited by Hans Steinmüller and Susanne Brandstädter, 1-13. London: Routledge.

Stoler, Ann Laura

2016 Duress: Imperial Durabilities in Our Times. Durham, N.C.: Duke University Press.

Weiss, Brad, ed.

2004 Producing African Futures: Ritual and Reproduction in a Neoliberal Age. Leiden: Brill.

2009 Street Dreams and Hip Hop Barbershops: Global Fantasy in Urban Tanzania. Bloomington: Indiana University Press.

Werbner, Pnina, Martin Webb, and Kathryn Spellman-Poots, eds.

2014 The Political Aesthetics of Global Protest: The Arab Spring and Beyond. Edinburgh:

Yurchak, Alexei Edinburgh University Press.

1997 "The Cynical Reason of Late Socialism: Power, Pretense, and the Anekdot." Public Culture 9, no. 2: 161-88. https://doi.org/10.1215/08992363-9-2-161.

2006 Everything Was Forever, Until It Was No More: The Last Soviet Generation. Princeton, N.J.: Princeton University Press. 